\title{
Capitals, trajectòries i estratègies: la teoria general dels camps de P. Bourdieu
}

\section{Ignasi Brunet I cart}

Universitat Rovira i V irgili. D epartament de Sociologia. Tarragona. Spain

\section{Antoni M orell Blanch}

Universitat de Lleida. D epartament de Sociologia. Lleida. Spain

\section{Resum}

El model de classes de P. Bourdieu articula la dimensió objectiva - l'estructura de classei la dimensió subjectiva - l'acció de classe- . Aquesta anàlisi de classe forma part d'un debat al voltant de la naturalesa de la realitat social, en el qual el punt més important és la connexió del camp de la producció i del camp de la reproducció de subjectes. Bourdieu, en enfasitzar la condició relacional de l'àmbit social, defineix l'acció social com a dependent de l'estructura relacional, en existir una connexió lògica necessària entre la localització dels agents en un conjunt de relacions socials i els seus interessos, objectius i estratègies d'acció. Per tant, per a aquest autor, hi ha una eficàcia estructuradora de l'acció dels agents social s per l'estructura de classe, i es constitueix, així, en una matriu d'acció, o millor dit, en una estructura probabilística de l'acció. És, doncs, fonamental, considerar el paper de l'acció en la construcció de les classes en si, ja que les classes teòriques, agrupacions fictícies que només existeixen sobre el paper, estan predisposades a convertir-se en classes en el sentit marxista del terme. I sols es passa de la classe sobre el paper a clase real a costa d'una labor política de movilització. Així, l'existència de classes, tant en la teoria com en la realitat, és una aposta de lluites en existir un espai social, un espai de diferències, en el qual les classes existeixen en estat virtual, no com quelcom donat, sinó com quelcom que es tracta de construir.

Paraules clau: classes socials, camp, habitus, capital, trajectòria, estratègia.

Abstract. Capitals, paths, strategies: P. Bourdien's general theory of fields

P. Bourdieu's model of classes articulates the objective dimension - class structure - and the subjective dimension - class acion. This class analysis takes place around a debate about the nature of social reality in which the main point is the connexion between the production field and the subjects reproduction field. Bourdieu, in emphasizing the relational condition of the social area, defines the social action as relational structure dependent, because there is a logic connection between the agents located in a set of social relations and their interests, objectives and action strategies. In Bourdieu's view there is an structuring efficiency of the social agents action by the class estructure, thus becoming an action matrix, or putting it better, a probabilistic structure of the action. Therefore, it's basic to understand the role of the action in the construction of the classes, given that the theoric classes, fictitious associations that only exist on the paper, are predisposed to become classes in the marxist sense of the word. And on the paper classes become real classes only 
through a political activism work. Thus, class existence, in theory as in reality, it's a bet of fightings in existing a social space, a differences space, in which classes exist in virtual state, not as something given, but as something that is trying to be constructed.

Key words: social classes, field, habitus, capital, path, strategy.

\section{Sumari}

1. Introducció: la teoria general dels camps de P. Bourdieu

2. La classe construïda: el moment sincrònic
3. Classe social i trajectòria: moment diacrònic

4. Conclusions

Bibliografia

\section{Introducció: la teoria general dels camps de P. Bourdieu}

En la teoria general dels camps, Bourdieu ens situa en un tipus de pensament relacional i analògic, que s'oposa directament a la hiperacionalitat dels models $\mathrm{d}^{\prime}$ elecció racionall ${ }^{1}$. M odels que prescriuen que els fenòmens socials han d'explicar-se partint exclusivament de les propietats, els fins, les creences i les accions dels individus. Pels individualistes metodològics, les condicions formals de l'explicació científica són aquelles condicions i/o mecanismes que generen una acció partint de la situació subjectiva d'un agent social, i aquelles condicions que generen un estat social agregat partint de la composició de les accions individuals (Elster, 1991 i De Francisco, 1996).

La noció d'habitus que elabora l'autor, a partir d'una teorització sobre l'estructura social i la producció de subjectes en una societat de classes, nega la concepció finalista de la pràctica perquè considera «[... ] que les conductes (econòmiques 0 d'altres) adopten la forma de seqüències objectivament orientades per referència al seu fi, sense ser necessàriament el producte, ni d'una

1. Sayer i Walker (1994) afirmen que tot l'àmbit de la sociologia arrela en l'intent de recuperar les relacions socials (i l'opressió social) del cubell de les escombraries després de la metamorfosi radical de l'economia política clàssica en economia neoclàssica a final del seglexıx. D e fet, la «violència de l'abstracció econòmica no és tan sols el resultat d'un error dels economistes: capta una inversió ideològica, un procés real de transformació cap a la integració del mercat, la circulació de les mercaderies i la conducta burgesa (Sayer, 1987). Sens dubte, l'ascens del capitalisme es va traduir en un triumvirat d'individualisme possessiu, càlcul despietat i obtenció furiosa de beneficis que alteraren fonamentalment la forma de pensar i de comportar-se de la gent, la forma com els individus es tractaven entre ells i tractaven la naturalesa (M acPherson, 1962; H abermas, 1971). La teoria neoclàssica no és, doncs, una mera descripció del món, sinó una carta en blanc per a la dominació capitalista, una idealització extremament parcial de la societat burgesa. Com M arx, Durkheim i Polany sostenen apassionadament, des d'angl es diferents, la conducta egoista pura, les nues relacions de mercat i l'explotació desenfrenada no poden ésser tolerades, fins i tot, si la burgesia triomfa; cal reelaborar l'edifici social per posar límit a les pitjors monstruositats del sistema» (A. Sayer.; R. Walker, 1994: 169). 
estratègia conscient, ni d'una determinació mecànica»2. Per l'autor, I'habitus, entès com un «sistema de disposicions adquirides en la relació amb un cert camp, es torna eficient, operant, quan troba les condicions de la seva eficàcia, és a dir, condicions idèntiques o anàlogues a aquelles de les quals és producte. Es torna generador de pràctiques immediatament ajustades al present i, fins i tot, a l'avenir inscrit en el present (d'allí la il·lusió de finalitat) quan troba un espai que proposa a títol de possibilitats objectives allò que porta en ell mateix a títol de propensió (a estalviar, a intervenir, etc.) de disposició (al càlcul, etc.) perquè es va constituir per la incorporació de les estructures (científicament apreheses com a possibilitats) d'un univers semblant» (P. Bourdieu, 1988a: 111).

L'habitus es defineix, doncs, com un sistema de principis generadors de pràctiques, apreciacions i percepcions. Sistema que és incorporat al Ilarg de la història de l'individu mitjançant un procés de «familiarització pràctica» amb uns espais i unes pràctiques produïts seguint els mateixos esquemes generatius.

Bourdieu intenta defugir tant la il/lusió objectivista3 - característica, entre d'altres, de l'antropologia estructuralista (Bourdieu, 1991: 73) - com la il.lusió subjectivista. En aquest sentit, l'autor critica les teories interaccionistes, fenomenològiques i etnometodològiques pel fet que no posen en relació l'element subjectiu amb les posicions que ocupen els agents en l'estructura: per ell, la construcció social de la visió del món es realitza sota coaccions estructurals $s^{4}$. És a dir, la construcció del món social s’articula al voltant de la producció diferencial dels esquemes cognitius i valoratius dels agents, ja que aquests no són únicament la posició actual que ocupen, sino també la història incorporada de les seves posicions anteriors. És per això que subjectes en posicions idèntiques produeixen estratègies diferents.

El principi de «no-consciència» que formula Bourdieu, es basa en la tesi que la vida social no pot explicar-se per les idees que en tenen els agents, sinó per causes més profundes que escapen de la seva consciència. Però no és menys cert que captar les opinions i les aspiracions dels subjectes, tal i com ells creuen que succeeixen les coses al món, és la condició bàsica per a la comprensió total de les representacions i les relacions viscudes pels subjectes - amb la seva «veritat»- en un sistema de relacions objectiu.

Cal, doncs, que la ciència social superi la falsa oposició entre subjectivisme i objectivisme, entre individualisme i «holisme» metodològic. La teoria sobre les classes socials és una bona mostra de l'oposició fictícia que enfronta els objectivistes marxistes i els subjectivistes weberians: «L'oposició entre una mecànica de les relacions de força i una fenomenologia o una cibernètica de

2. Concepció que deriva del fet que els individus estan imbricats en una trama social de pràctiques i d'institucions, de concepcions i de morals que és impossible dissoldre (P. Bourdieu, 1980).

3. Certament, les xarxes de posicions objectives determinen en bona mesura les opcions dels agents; però això no treu que aquests siguin el fruit d'una història personal i social que els orienta en la mobilització dels recursos, propietats i posicions socials.

4. S'allunya, en aquest punt, de les tesis mantingudes per Berger i Luckman, entre d'altres. 
les relacions de sentit mai és tan visible, i tan visiblement estèril, com en la teoria de les classes socials. D 'una banda, les definicions estrictament objectivistes que, com la vessant economicista de la teoria marxista, busquen el principi de la determinació de les classes en unes propietats que no deuen res a la percepció o a l'acció dels agents [... ]; d'altra banda, les definicions subjectivistes o nominalistes, tant si es tracta de la teoria weberiana del "grup d'estatus" que privilegia les propietats simbòliques constitutives de l'estil de vida, com de les anàlisis empíriques, tendents a establir si, i com, les classes existeixen en la representació dels agents» (P. Bourdieu, 1991: 229).

\section{La classe construïda: el moment sincrònic}

Bourdieu (1988a: 85), defugint tant l'intel'lectualisme del càlcul econòmic com les «ingenuïtats del subjectivisme», considera que cal «comprendre la lògica específica de totes les accions de classe que, essent raonables, no són el producte d'un càlcul racional ni d'un inconscient definit com un operador mecànic d'efectes».

Bourdieu parteix de la definició de classe objectiva com «un conjunt d'agents que es troben situats en unes condicions d'existència homogènies que imposen uns condicionaments homogenis i produeixen uns sistemes de disposicions homogenis, apropiats per engendrar unes pràctiques semblants, i que posseeixen un conjunt de propietats comunes, propietats objectivades, de vegades garantides jurídicament (com la possessió de béns o de poders) o incorporades, com I'habitus de classe (i, en particular, els esquemes classificadors)» (1991: 11). L'habitus és, per tant, la classe incorporada: «la sociologia tracta com a idèntics tots els individus biològics que, essent el producte de les mateixes condicions objectives, estan dotats del mateix habitus i classe de condicions d'existència i de condicionaments idèntics o semblants, la classe social (en ella mateixa) és inseparablement una classe d'individus dotats del mateix habitus [... ] Si està exclòs que tots els membres de la mateixa classe (o fins i tot de dues d'elles) hagin passat les mateixes experiències i en el mateix ordre, és cert que qual sevol membre de la mateixa classe té probabilitats més grans que qual sevol membre d'una altra classe de trobar-se confrontat a les situacions més freqüents per als membres d'aquesta classe» (Bourdieu, 1980: 100).

La classe social no ve definida per una propietat, per una suma de propietats, o per una cadena de propietats ordenades a partir d'aquella que resulta ser la fonamental. La classe social es defineix per l'estructura de relacions entre les propietats, que són les diverses formes de capital 5 (econòmic, cultural 0

5. L'estructura del capital pot ser simètrica (aquest seria el cas del s directius que disposen alhora d'un bon capital cultural, econòmic i social) o asimètrica (com succeeix en els empresaris que tenen bastant o molt capital econòmic i poc capital cultural, per exemple). A La distinción (1988b) i a La noblesse d'État, (1989b) s'observa que les classes socials, segons el seu volum i estructura patrimonial, es distribueixen en forma d'entrecreuament d'aspa: I'estructura de distribució del capital econòmic és simètrica i inversa a l'estructura del capital cultural. 
social) objectivat i/o incorporat, que, combinat d'una manera determinada, produeix la configuració singular que caracteritza una classe: la seva estructura patrimonial. Certament, Bourdieu (1969: 73) no nega que determinats tipus d'estructura social puguin donar lloc a posicions de classe diferents, però considera que les classes socials no poden definir-se exclusivament per la seva posició en l'estructura social; és a dir, per les relacions que objectivament mantenen amb les altres classes socials.

Per tant, cal pensar les classes socials i l'estructura de classes en termes d'una estructura de relacions sobredeterminada, ja que «la causalitat estructural d'una xarxa de factors és completament irreductible a l'eficàcia acumulada del conjunt de les relacions lineals de força explicativa que les necessitats de l'anàlisi obliguen a ailllar, aquelles que s'estableixen entre els diferents factors agafats un a un i la pràctica considerada; mitjançant cada un dels factors, s'exerceix l'eficàcia de tots els altres, ja que la multiplicitat de determinacions no condueix a la indeterminació, sinó, per contra, a la sobredeterminació (Bourdieu, 1988b: 105-106). $\mathrm{N}$ o es pot reduir el subjecte a la seva posició actual, ja que els subjectes excedeixen les seves posicions (en el temps - els subjectes no són sols la seva posició actual, sinó també la història de les seves posicions anteriors- i en l'espai - els subjectes ocupen diverses posicions en diversos camps socials- ). I és que els subjectes no són mers ocupants de les posicions, són també subjectes d'estratègies.

L'estructura patrimonial definitòria de la classe no es forma tan sols de capital econòmic, cultural i social. A aquests, s'hi ha d'afegir el «capital simbò$\mid i c »$, és a dir, la forma que prenen la resta de capitals «quan és percebuda a través de les categories de percepció que només coneixen la lògica específica i que, en canvi, desconeixen el caràcter arbitrari de la seva possessió i de la seva acumulació» (Bourdieu i Wacquant, 1994: 96). La importància del capital simbòlic rau en el fet que, per Bourdieu, I'oposició entre classe social i grup d'estatus no s'ha d'entendre com a dos tipus d'unitats reals, sinó com a dues unitats nominals que són «el resultat de l'elecció d'accentuar l'aspecte econòmic o l'aspecte simbòlic, aspectes que coexisteixen sempre en la realitat (en proporcions diferents segons les societats i segons les classes socials d'una mateixa societat), ja que les distincions simbòliques són sempre secundàries respecte a les diferències econòmiques que expressen» ( $P$. B ourdieu, 1969: 87).

Tornant al tema que estàvem plantejant, no podem deixar de preguntarnos d'on deriva la lògica específica de les accions de classe a les quals fèiem esment. Q üestió que ens retorna necessàriament a la noció d'habitus. Com ens recorda Bourdieu (1983), E. Panofsky emprà aquesta noció aristotèlicotomista - plantejada tradicionalment com a raó pràctica- en la seva obra Architecture gothi que et pensée scolastique, per tal de reflectir la relació existent entre les catedrals gòtiques i el pensament escolàstic en el segle XIII: Ia noció d'habitus va permetre l'autor comprendre com l'individu creador de catedrals participa del conjunt social i de la seva època històrica que orienta i dirigeix les accions creatives que aparentment són úniques i singulars. 
A partir d'aquests antecedents, l'habitus esdevindrà un concepte clau en l'obra de Bourdieu per comprendre com els subjectes produeixen les seves estratègies i per què habitualment serveixen a la reproducció de la seva posició en el sistema social. Per Bourdieu els individus no reaccionen davant de condicions objectives, sinó davant de condicions apreheses mitjançant principis socials constituïts que són els que organitzen la seva percepció. Per tant, les condicions materials d'existència característiques d'un particular tipus de condició de classe ${ }^{6}$, produeixen els habitus; i les pràctiques que produeixen els habitus, en tant que sistemes de disposicions durables, es troben preparades per funcionar com a estructures estructurants 7 , i permeten fer front a situacions noves i no previstes.

L'habitus exclou la deliberació i el càlcul estricte de probabilitats, ja que «com que és el producte de la incorporació de la necessitat objectiva [... ], produeix estratègies que, per més que no siguin el producte d'una tendència conscient de finalitats explícitament presentades sobre la base d'un coneixement adient de les condicions objectives, ni d'una determinació mecànica per les causes, es troba que són objectivament ajustades a la situació. L'acció que guia el "sentit del joc" té totes les aparences de l'acció racional que dissenyaria un observador imparcial dotat de tota la informació útil i capaç de dominar-la racionalment. I, això no obstant, no té la raó per principi [... ]. Les condicions del càlcul racional no es donen gairebé mai a la práctica: el temps és comptat, la informació, limitada; etcètera. I, malgrat tot, els agents fan, molt més sovint que si procedissin a l'atzar, "I'únic que poden fer". I això perquè, abandonantse a les intuïcions d'un "sentit pràctic" que és producte de l'exposició durable a les condicions semblants 0 a aquelles en les quals estan col·locats, anticipen la necessitat immanent al curs del món» (P. Bourdieu, 1988a: 22-24).

L'habitus s'emmarca dins dels límits de la producció històrica i social, i sallunya tant del determinisme mecanicista, com de la llibertat incondicional i incondicionada, ja que s'oposa per igual a la necessitat mecànica i a la llibertat reflexiva, a les coses sense història de les teories mecanicistes i als subjectes «sense inèrcia» de les teories racionalistes. El programa que $\mathrm{M}$ arx

6. Cal no oblidar que l'habitus és un sistema subjectiu - subjectiu no significa individuald'estructures interioritzades, esquemes de percepció i d'acció, que són comuns a tots els membres d'un mateix grup o classe social. És per aquest motiu que la individualitat orgànica - l'existència de la qual Bourdieu no qüestiona en cap moment - no contradiu I'existència d'un habitus de classe. Ben al contrari, I'autor considera que condicions d'existència idèntiques tendeixen a produir sistemes de disposicions semblants. Aquesta homogeneïtat relativa dels habitus dels agents rau en el principi d'una harmonització objectiva de les pràctiques i de les seves obres. Aquest principi tendeix a conferir regularitat i objectivitat a les accions i representacions que fan els agents d'una mateixa classe. En definitiva, l'habitus constitueix la condició de qual sevol objectivització i de qual sevol percepció en basar la concertació objectiva de les pràctiques i la unicitat de la visió del món, sobre la impersonalitat i la substitució perfecta de les pràctiques i de les visions singulars.

7. Ara bé, I'habitus no és tan sols estructura estructurant, sinó també estructura estructurada, és a dir, no tan sols organitza les pràctiques i la seva percepció, sinó que al hora incorpora la divisió per classes socials a través de símbols distintius. 
proposa en la primera tesi sobre Feuerbach ${ }^{8}$ fa possible una teoria materialista del coneixement que rebutja la noció idealista que tot coneixement pressuposa un treball de construcció (P. Bourdieu, 1994: 98). La noció d'habitus permet, basant-se en aquesta primera tesi de $M$ arx a Feuerbach, crear les condicions de possibilitat d'una ciència social que no ignori la capacitat creadora dels individus, però que alhora la situï en les condicions materials d'existència de la qual és producte. En definitiva, el debat de $M$ arx amb Feuerbach permet a Bourdieu constituir l'agent social com un operador pràctic de construccions pràctiques. I és que el concepte d'habitus és indissociable del de «racionalitat pràctica». Racionalitat que pressuposa un sistema de categories i d'esquemes cognitius a partir dels quals es donarà sentit a la situació, se seleccionarà la informació rellevant i es produiran les pràctiques i decisions. Aquests sistemes no són iguals per a tots els individus, ja que depenen de la trajectòria social, és a dir, del conjunt de posicions ocupades en les diferents institucions socials $i$, sobretot, de la posició familiar en l'estructura social (E. M artin; J. Izquierdo, 1992-1993).

\section{Classe social i trajectòria: moment diacrònic}

Per tal d'arribar a comprendre les pràctiques dels agents no és suficient conèixer el volum i l'estructura dels capitals que sobreviuen en l'habitus (moment sincrònic), sinó que és necessari conèixer la relació estadística - d'intensitat variable - entre la posició social original, la present i la potencial. La trajectòria social ${ }^{9}$ (moment diacrònic) ens permet explicar per què agents idèntics (en el moment sincrònic) quant a l'estructura patrimonial, desenvolupen pautes de comportament i estratègies diferents.

Tal com ens explica Bourdieu (1969: 78-79), la posició d'un agent o d'una classe en l'estructura social, «mai pot definir-se completament des d'un punt de vista estrictament estàtic, és a dir, com a posició relativa ("superior", "mitjà" o "inferior") dins d'una estructura en un moment donat del temps: el punt de la trajectòria, captat per un tall sincrònic, conté sempre el declivi del trajecte social: per tant, sota pena de deixar escapar tot allò que defineix concretament l'experiència de la posició com una etapa d'un ascens o d'un descens, com pro-

8. «El principal defecte de tots els materialismes, fins i tot el de Feuerbach, rau en el fet que l'objecte es concep en ells tan sols sota la forma d'objecte de percepció, però no com a activitat humana, com a pràctica».

9. En l'anàlisi de la trajectòria s'han de considerar tres efectes diferents: a) l'efecte de la situació professional, per exemple; b) l'efecte del medi professional, ja que els membres d'una classe (o fracció de classe) i les seves disposicions - especialment les culturals, religioses i polítiques- es troben marcades per l'efecte de la posició en la distribució de propietats secundàries - el gènere, l'edat, l'ètnia o l'ascens social, entre d'altres- que marquen la identitat dels seus membres, i c) l'efecte del temps d'ascens a la posició social, ja que l'edat a la qual s'accedeix a una determinada posició social expressa la divisió entre tota la trajectòria anterior i la posterior, així com el volum i l'estructura del capital que determina la trajectòria. 
moció o retrocés, és necessari caracteritzar cada punt pel diferencial de la funció que expressa la corba, és a dir, per tota la corba».

Els agents socials no tan sols posseeixen uns determinats capitals, sinó que també desenvolupen estratègies per tal de conservar-los i augmentar-los. Els diversos grups - definits per la seva posició en l'estructura de capital- produeixen subjectes adients a les condicions materials i socials en les quals són produïts, i, mitjançant aquesta producció, reprodueixen les seves posicions en l'estructura social. Les estratègies de reproducció són el conjunt de pràctiques «a través de les quals els individus o les famílies tendeixen, de manera conscient 0 inconscient, a conservar 0 a augmentar el seu patrimoni i, correlativament, a mantenir o millorar la seva posició en l'estructura de posicions de classe, constitueixen un sistema que, en ser producte d'un mateix principi unificador i generador, funciona i es transforma com a sistema» (P. Bourdieu, 1991: 122).

Per tal d'analitzar el sistema d'estratègies de reproducció10/reconversió de capitals que desenvolupa una classe o un grup, cal tenir en compte dos nivells diferents: I'estructura patrimonial i els instruments de reproducció disponibles.

Pel que fa a l'estructura patrimonial, «no tots els agents ni tots els grups utilitzen de la mateixa manera, ni en el mateix grau, totes les estratègies de reproducció possible. El sistema d'estratègies de reproducció que realment es posen en acció per cadascun depèn en cada cas del volum i, sobretot, de l'estructura del seu patrimoni: principalment és a través de l'estructura d'oportunitats diferencials de benefici, que s'ofereixen objectivament a les inversions per part dels diferents mercats socials, com s'imposen estructures diferents de tendències d'inversió 0 , si es prefereix, de sistemes de preferències 0 d'interessos diferents» (Bourdieu, 1989a: 392).

$D$ 'altra banda, pel que fa als instruments de reproducció, Bourdieu dóna una gran importància a la família escola: «el sistema de producció de béns culturals o el sistema de producció dels productors desenvolupen per afegiment, és a dir, per la lògica mateixa del seu funcionament, unes funcions ideològiques, perquè els mecanismes pels quals contribueixen a la reproducció de l'ordre social i a la permanència de les relacions de dominació romanen amagades» (1991: 223-224).

En qualsevol cas, cal no oblidar que les pràctiques troben el seu principi motor en I'habitus, de tal forma que les estratègies no poden ésser analitzades com un projecte explícit i conscient: les pràctiques, suggerides per l'habitus, sorganitzaran objectivament sense haver estat concebudes explícitament com un projecte de reproducció, mal grat que contribueixin a la tasca de reproducció de capitals. I és que les dinàmiques de reproducció social no poden ésser enteses com a dinàmiques mitjançant les quals la societat es reprodueix ella

10. Bourdieu (1989a) diferencia fins a vuit estratègies de reproducció de capital: les estratègies de fecunditat; les estratègies de successió; les estratègies educatives; les estratègies profilàctiques; les estratègi es (pròpiament) econòmiques; les estratègi es d'inversió social; les estratè gies matrimonials, i les estratègies de «sociodicea» (simbòliques o ideològiques). 
mateixa, sinó com a dinàmiques mitjançant les quals les diverses classes socials s'enfronten en la lluita per les diferents espècies de capital: per la reproducció simple - manteniment- o ampliada - promoció- de la seva situació.

Ara bé, els capitals no tan sols es reprodueixen, sinó que es reestructuren per la necessitat d'evitar una devaluació en el patrimoni: «el fet que l'espai social està jerarquitzat en les seves dues dimensions - d'una banda, la del volum del capital global, des del més important fins al menys important; i, d'altra banda, la de l'espècie de capital dominant a l'espècie de capital dominat ${ }^{11}$ _ permet dues formes de desplaçament que els tradicionals estudis de mobilitat confonen, malgrat que de cap manera siguin equivalents i malgrat que siguin molt desigual ment probables: en primer lloc, els desplaçaments verticals, ascendents o descendents, en el mateix sector vertical de l'espai, és a dir, en el mateix camp (com el mestre que arriba a professor, el petit patró que arriba a gran patró); després, els desplaçaments transversals, que impliquen el pas d'un camp a un altre de diferent i que podent realitzar-se bé en el mateix pla horitzontal (quant el mestre, o el seu fill, es fan petits comerciants), bé en plans diferents (com el mestre - 0 el seu fill- que arriben a patró d'indústria). Els desplaçaments verticals, que són els més freqüents, impliquen només una modificació del volum de l'espècie de capital ja dominant en l'estructura patrimonial (del capital escolar en el cas del mestre que arriba a professor) i, per consegüent, un desplaçament en l'estructura de la distribució del volum global del capital que adopta la forma d'un desplaçament en els límits d'un camp específic (camp empresarial, camp escolar, camp administratiu, camp mèdic, etc.). Per contra, els desplaçaments transversals impliquen el pas a un camp diferent $i$, en conseqüència, la reconversió d'una espècie de capital en una altra espècie diferent, o d'una subespècie de capital econòmic o de capital cultural en una altra de diferent (per exemple, de propietat agrícola a capital industrial, o d'una cultura literària o històrica a una cultura econòmica), i, per tant, una transformació de l'estructura patrimonial que és la condició de salvaguarda del volum global del capital i del manteniment de la posició en la dimensió vertical de l'espai social» (P. Bourdieu, 1988a: 129).

Les estratègies de reproducció o de reconversió del capital que pot utilitzar cada agent no són lliures, sinó que, a més del volum de capital (actual i potencial) i de la seva estructura, es troben condicionades per la classe a la qual es pertany 0 , més correctament, depèn del sistema d'instruments de reproducció - institucionalitzats o no- d'acord amb la situació de lluita entre les diferents classes socials. Així, sota l'aparença de trajectòries individuals, Bourdieu

11. Les estratègies simbòliques busquen donar legitimitat a la dominació dels diferents tipus de capital, i molt especial ment al tipus de capital en el qual resideix el poder i a la manera de reproducció associada a aquest poder. C ertament, les estratèies a través de les quals els grups socials busquen mantenir la seva situació privilegiada no son fruit d'un poder que s'expressi mitjançant la coerció física continuada: «cap poder es conforma a existir com a poder, és a dir, com a força nua, desprovista de tota justificació, en una paraula arbitrària, sinó que ha de justificar la seva existència, i existir com existeix, 0 , si més no, fer no reconèixer (ménconnaître) l'arbitrarietat que està en el seu fonament i, per aquí, fer-se reconèxxer com a legítima». (P. Bourdieu, 1989a: 337). 
descriu i explica trajectòries socials que són trajectòries de classe, ja que a una estructura i volum de capital heretat li correspon un ventall de trajectòries més o menys equiparables ${ }^{12}$ que porten a posicions més o menys equivalents. L'específic de la trajectòria individual serà la desviació respecte a la trajectòria modal d'una classe: el desclassament produït, no respecte a una posició, sinó al pendent (orientació, sentit) d'una trajectòria de classe. Per tant, si bé Bourdieu considera l'existència d'una correlació estadística entre capital d'origen i capital d'arribada, no justifica un a pri ori en les trajectòries dels agents; aquests es desviaran, per sobre o per sota, respecte a la trajectòria del conjunt dels agents - és a dir, la trajectòria modal- .

Així doncs, les estratègies individuals o col-lectives de reproducció/reconversió només es poden comprendre en referència a l'espai social que les defineix i que aquestes estratègies tracten de mantenir o redefinir. L'espai social constitueix un camp de lluita en el qual, com a sistema de relacions objectives, les posicions es defineixen relacional ment i que domina, a més, les lluites que intenten transformar-lo. El camp social - concepte que permet a Bourdieu trencar amb les ambigües referències que denoten paraules com «medi», «context», etc. - és un espai de joc històricament constituït amb institucions i lleis de funcionament pròpies, correlatives a interessos i compromisos específics.

Els agents socials, per tal d'ésser membres actius del camp, han de posseir les propietats necessàries per produir efectes en aquest camp. És a dir, hi ha uns drets d'entrada - uns capitals específics - que són requisits necessaris i legítims. D es d'aquesta perspectiva, la noció d'interès és una noció concreta; a diferència de l'interès natural, no històric i genèric del s economistes, l'interès, per Bourdieu (1988a) rau en la inversió en un joc. L'interès és la condició d'entrada en el joc. Hi ha, per tant, tantes formes d'interès com camps.

$\mathrm{H}$ abitus i camp, com a conceptes relacionals, no poden funcionar l'un sense l'altre. En cada camp trobem un conjunt d'agents socials que «es presten al joc» (P. Bourdieu, 1980: 114), dotats d'un habitus que implica el coneixement i el reconeixement de les lleis immanents al joc i a les seves apostes. Aquesta és una de les propietats importants del camp, ja que en el joc hi ha un conjunt de coses que s'admeten i que no es discuteixen. Però lluny de tractar-se d'ignorància, es tracta de la impossibilitat de distingir un fet ja conegut.

En definitiva, els agents, els grups, o les classes socials, depenen de l'estructura i del volum de capital, dela trajectòria i del seu habitus (disposicions) per realitzar les seves estratègies en un camp. És a dir, les relacions de força depenen de la tríada conceptual capital-habitus-camp, tenint en compte, en tot cas, que existeixen unes regl es tàcites del camp i unes necessitats de reproducció d'aquest, que defineixen allò que pot ser dit i fet, per bé que els agents socials poden lluitar per tal de transformar les regles i fer dominant el valor de l'espècie de capital per al qual estan més preparats.

12. Trajectòries modals: trajectòries típiques que haurien de recórrer els qui hereten un determinat capital. 


\section{Conclusions}

La perspectiva teoricometodològica de Bourdieu resulta incompatible amb l'individualisme metodològic, Pel que fa als models d'elecció racional, cal assenyalar que enfront de l'individual isme metodològic de l'home econòmic racional ${ }^{13}$, I'autor considera tot subjecte com a subjecte estratègic que realitza jugades en els diversos camps en els quals es troba a partir d'una racionalitat pràctica, i que suposa una determinada forma de calcular costos i beneficis.

En qualsevol cas, per tal d'evitar les crítiques més superficials que s'han fet a la seva obra, cal precisar que l'habitus dóna un cert marge d'elecció. La qüestió rau a esbrinar fins a quin punt té sentit parlar de l'adopció d'estratègies conscients per part dels actors. La clau d'aquest interrogant (G il Calvo, 1993) resideix en el fet de reconèixer la impossibilitat d'identificar els objectius estratègics de l'acció amb les intencions conscients explícitament manifestades pels seus actors.

Entendre el concepte d'habitus ens obliga a distingir entre racionalitat i raonabilitat. «La primera se suposa universal, la segona és particular. La primera implica una percepció de la situació que es correspon objectivament amb ella. La segona implica diverses apreciacions de la situació segons interessos i esquemes cognitius entre els quals no es pot establir una jerarquia universal. La «raonabilitat» es refereix a l'adequació pràctica a una situació concreta segons uns esquemes incorporats mitjançant la familiarització amb situacions semblants. Els pares no ensenyen els seus fills a ser «racionals» - a maximitzar la relació entre costos i beneficis- , sinó «raonables»: a comportar-se com convé a la situació. I, aprenent a ésser raonables, aprenen els principis de divisió del món: les categories, indissociablement cognitives i avaluatives» ( $M$ artin i Izquierdo, 1992-93: 130). Per tant, I'habitus, com a sistema de principis generadors de pràctiques, apreciacions i percepcions, no és racional ni irracional, és raonable.

La teoria econòmica neoclàssica es correspon en sociologia amb la teoria funcionalista i, fins a cert punt, amb la teoria del capital humà. Aquesta última parteix de la idea que l'origen de tots el fenòmens socials s'ha de buscar en la conducta individual. Schultz, Becker i M incer, entre d'altres, consideren que la formació de capital humà es realitza mitjançant individus que actuen per compte propi (Blaug, 1983: 69). L'individual isme metodològic és un individual isme ontològic, perquè planteja les relacions socials (laborals, educatives, etc.) com a relacions interpersonals, és a dir, com a relacions interpersonals entre individus subjectes només a la maximització de les seves utilitats i amb un poder d'abstracció similar. Teoria, doncs, que afegeix a la teoria neoclàssica un nou factor: la idea de la inversió en capital humà complementa la tesi de la quantitat de treball oferta en el mercat amb la idea de la seva qualitat. La pre-

13. Q ualsevol subjecte en una mateixa situació de recursos i informació adoptarà la mateixa decisió. Per la teoria neoclàssica, la racionalitat individual i l'egoisme comportamental són dos supòsits centrals. 
Ignasi Brunet Icart; Antoni M orell Blanch

gunta clau és: per què els individus inverteixen en formació? A la qual es contesta mitjançant mecanismes innats o psicosocials: la taxa de preferència individual.

Però, com i on es produeixen les estratègies i les pràctiques dels agents? És a aquest interrogant al qual Bourdieu intenta donar resposta. Perquè qualsevol teoria científica encaminada a l'estudi del procés de formació/producció de les classes - i dels agents que en formen part- com a subjectes col·lectius, ha de passar per l'emfasització de la condició relacional dels fets socials.

Si els subjectes es defineixen segons les seves posicions en una matriu de relacions, cal evitar tota definició apriorística de les classes. Aquest és l'error que cometen, entre d'altres, Giddens i/o Parkin, quan expliquen els fenòmens socials a partir de les pràctiques i de les estratègies intencional s ${ }^{14}$ del s agents socials.

Bourdieu supera al guns d'aquests problemes mitjançant la utilització dels conceptes de camp, habitus i capital. Conceptes que permeten superar algunes de les limitacions que comporta tant la teoria de les classes de G iddens i Parkin, com les del marxisme analític (Roemer, Elster, Wright, etc.), que redefineix les divisions de classe des de la perspectiva de l'intercanvi de mercat: els teòrics marxistes contemporanis defensen en general algun tipus de primacia de les relacions de producció sobre les relacions de mercat. Un cop més, això no obstant, els desenvolupaments recents de la teoria marxista mostren una tendència a diluir l'especificitat de la perspectiva marxista en benefici d'una obertura més gran cap a les concepcions weberianes. Entre els economistes polítics marxistes, per exemple, hi ha una puixant escola de teòrics «sraffians» que sostenen quel'acumulació de capital sanalitza millor des dels fenòmens del mercat (salaris, preus, etc.) que des dels valors de producció definits per la teoria del valor-treball. En un dels treballs més provocatius de

14. Giddens, per exemple, centra la seva anàlisi en allò que anomena estratègi es d'estructuració de les classes «com un fenomen variable que intervé en les interconnexions entre l'economia i la societat. I les divisions de classes no poden traçar-se com les línies d'un mapa, i el grau en què es dóna l'estructuració de les classes depèn de la interacció entre diversos tipus de factors». A través del procés d'estructuració - mediata i immediata - les situacions econòmiques de mercat donen Iloc a les classes com a formes socials diferenciades ( $G$ iddens, 1979: 323-324). Parkin (1984), de la seva banda, fa l'èmfasi en allò que ell anomena estratè gies de tancament social, a través de les quals planteja l'estructura de classes articulada amb l'acció col·lectiva de les classes que competeixen en l'àmbit de la distribució a partir del mercat, és a dir, del conjunt d'estratègies de tancament social: la propietat, el llenguatge, I'origen ètnic, la religió, el gènere. Tots dos autors construeixen dos tipus d'arguments contra la dimensió estructural ista de la teoria marxista: «en primer lloc, mantenen que el marc de les explicacions marxistes basades en la lògica del tipus de producció constitueix una forma de funcionalisme, cosa que rebutgen per diverses raons: les explicacions funcionals són teològiques; imputen fal sament «necessitats» al sistema social; i així successivament. En segon Iloc, argumenten que el marxisme redueix els actors humans a «portadors» passius de les relacions socials, mancats de tot coneixement o intencionalitat. Sostenen que això és especialment problemàtic per una teoria que, com el marxisme, també pretén servir de guia a la política» (V. Burris, 1993: 131-132). 
la teoria marxista recent, John Roemer (1982) estén aquesta perspectiva a I'anàlisi de l'explotació $\mathrm{i}$ de les classes. Hi ha un altre apartat en el qual les relacions de mercat han aconseguit una gran acceptació en l'anàlisi marxista de les classes: «Em refereixo a l'anàlisi de les divisions fraccionals dins de les classes, i especialment dins de la classe obrera. En la dècada anterior els teòrics marxistes varen elaborar el concepte de "segmentació del mercat laboral" per tal de poder explicar les persistents divisions dins de la classe obrera. Des d'aquesta perspectiva, el fracàs dels treballadors en la consecució de la unitat de classe no és un mer reflex de les divisions culturals o de la falsa consciència, sinó que arrela més aviat en les diferències objectives en les condicions sota les quals les diverses faccions de treballadors venen la seva força de treball i en les corresponents diferències en la naturalesa dels llocs que acaben ocupant» (Buris, 1992: 150).

En qual sevol cas, per Bourdieu, el problema de les classes no és només el problema de la lluita de classes, sinó també el d'una lluita al voltant de les classes, és a dir, la disputa sobre si aquestes es constitueixen o no com a subjectes. L'anàlisi de classes permet a Bourdieu analitzar camps socials concrets, construir tipologies socials que servei xen de base al càlcul estratègic i fundar un programa d'investigació que indagui l'existència de tendències històriques en la formació dels subjectes a partir de l'estructura de les relacions socials.

La forma que adopta en un determinat camp el capital objectivat (les propietats, els capitals) i l'incorporat (l'habitus) ens explica un estat determinat de la distribució d'un tipus particular de béns, de disposicions o de pràctiques. El volum i l'estructura del capital (definits sincrònicament i diacrònicament) i del conjunt de propietats secundàries, conjuntament amb l'habitus, produeix els seus efectes en l'activació del camp, que afecten tots els jugadors que entren en aquest camp, perquè els camps tenen uns sistemes de relacions que són independents dels agents definits per aquestes relacions ${ }^{15}$, de tal forma que resulta possible anar de l'opus operatum (dels productes estructurats) al modus operandi (l'estructura estructurant), és a dir, de la regularitat estadística, al principi de producció de l'ordre observat, i construir la teoria de la pràctica. Però no es tracta d'elegir entre les estructures socials $\mathrm{i}$ els agents, entre la lògica del camp - que dota de sentit i valor les propietats objectivades - i els agents que desenvolupen les seves pràctiques en un espai de joc. Es tracta de reintroduir els agents dins del funcionament de les institucions socials, però sense oblidar que aquests són la personificació de les exigències reals o potencials inscrites dins l'estructura del camp, és a dir, dins de la posició ocupada a l'interior d'un camp determinat (econòmic, universitari, etc.).

15. Les propietats (cartes) que aporten els agents (jugadors) no són suficients per entendre el joc, és necessari entendre les regles immanents al joc. I això malgrat que el s jugadors poden desenvolupar estratègies per augmentar, conservar o transformar, d'acord amb els seus capitals, les regles tàcites del joc i les necessitats de reproducció del camp. 


\section{Bibliografia}

BOURDIEU, P. (1967). «C ampo intel-lectual y proyecto creador». A PoUILLON, J. i altres. Problemas del estructuralismo. M éxico: Siglo XXI.

- (1969). «C ondición de clase y posición de clase». Estructurali smo y sociología. Buenos Aires: Nueva Visión, p. 73-100.

- (1971). «G énese et structure du champ religieux» Revue F rançaise de Sociologie, XII. París.

- (1972). Esquisse d'une théorie de la practique. Précédée de trois études d'etnologi e Kabyle. Ginebra: D roz.

- (1974). «Avenir de classe et casualité du probable» Revue Française de Sociologie, vol. 15, 1, p. 3-42.

- (1976). «Le capital social. N otes provisoires». Actes de la recherce en sciences sociales, 31, p. 2-3.

- (1978). «Reproducción cultural y reproducción social». Política, igualdad social y educación. M adrid. M EC.

- (1980). Questions de sociologie. París: Ed. de M inuit.

- (1982). Leçon sur la leçon. París: Ed. de M inuit.

- (1983). «Simbologia i pensament escolàstic. A propòsit d'Architecture et pensée scolastique». Papers, 31, p. 9-33.

- (1985a). «Sistemas de enseñanza y sistemas de pensamiento». A GIM EN o SACRIST Án, J.; PÉrez Góm mz, A. (comps.). La enseñanza, su teoría y su práctica. M adrid: Akal.

- (1985b). ¿Q ué significa hablar? Economía de los intercambios lingüísticos. M adrid: Akal.

- (1988a). Cosas dichas. Barcelona: G edisa.

- (1988b). La distinción, criterio y bases sociales del gusto. M adrid: Taurus.

- (1989a). «La ilusión biográfica». H istoria y fuente oral. núm. 2.

- (1989b). La noblesse d'É tat. Grandes É coles et esprit de corps. París: Ed. de M inuit.

- (1992). «Posfacio» Paul Rabinow, Reflexiones sobre un trabajo de campo en M arruecos. Barcelona: Júcar.

BOU RDIEU, P.; SAINT-M ARTIN, M . (1978). Le patronat. Actes de la recherche en sciences socials.

Bourdieu, P.; W acquant, L.J.D. (1993). La mi sère du monde. París: Seuil.

- (1994). Per a una sociologi a reflexiva. Barcelona: H erder.

BuRRIS, V. (1992). «La síntesis neomarxista de M arx y W eber sobre las clases». A

Carabañ A, J.; D e Fran cisco, A. (comp.). «Teorías contemporáneas de las clases sociales». Zona Abierta. M adrid, núm. 59-60.

ELSTER, J. (1991). U na introducción a Karl M arx. M adrid: Siglo XXI.

Fran CISCO, Andrés de (1996). Sociología y cambio social. Barcelona: Ariel.

GarRid o M edin A, L.; GIL Calvo, E. (1993). Estrategiasfamiliares. M adrid: Alianza.

GID DEN S, A. (1979). La estructura de clases en las sociedades avanzadas. M adrid: Alianza.

GIDDENS, A. i altres (1990). La teoría social, hoy. M adrid: Alianza.

GIL Calvo, E. (1993) «La hipòtesis del rol "egoísta". Límites de la teoría de la elección racional». A LAM O DE ESPIN OSA; Rod RígUez I BÁÑEZ. Problemas de la teoría social contemporánea. M adrid: CIS.

M ARTIN , E.; IZQUIERD O, J. (1992-93). «Elementos para una sociología económica de la gestión empresarial de la fuerza de trabajo». Sociología del Trabajo, núm. 17.

Park IN, F. (1984). M arxismo y teoría de clases. M adrid: Espasa-C alpe.

SAYER, A.; W ALKER, R. (1994). La nueva economía social. M adrid: M TSS. 